\title{
Hubungan Pengetahuan dengan Sikap Ibu Nifas tentang Perawatan Luka Perineum di RSU GMIM Pancaran Kasih Manado
}

\author{
Fredrika Nancy Losu ${ }^{1}$, Femmy Keintjem ${ }^{2}$, Sridayanti Binambuni ${ }^{3}$ \\ 1,2,3 jurusan Kebidanan Politeknik Kesehatan Kemenkes Manado, \\ Email : nancy_losu@yahoo.com
}

\begin{abstract}
ABSTRAK
Latar Belakang: Robekan perineum adalah robekan yang terjadi pada saat bayi lahir, baik secara spontan maupun dengan menggunakan alat atau tindakan persalinan. Robekan perineum terjadi pada hampir semua primipara. Perdarahan pasca persalinan dengan uterus yang berkontraksi baik biasanya disebabkan oleh robekan serviks atau vagina.

Tujuan: mengetahui Hubungan Pengetahuan dengan Sikap Ibu Nifas tentang Perawatan Luka Perineum di RSU GMIM Pancaran Kasih Manado

Metode: Jenis penelitian menggunakan observasional analitik. Penelitian ini dilakukan pada ibu nifas dengan luka perineum, dan teknik pengambikan sampel dengan purposive sampling dengan jumlah sampel sebanyak 40 responden.

Hasil: Analisis uji chi square, diperoleh nilai Exact Sig. (2-sided) sebesar 0.021 menunjukkan hasil signifikan lebih kecil dari $0.05(0.021<0,05)$.

Kesimpulan: Ada hubungan antara pengetahuan dengan sikap ibu nifas tentang perawatan luka perineum di RSU GMIM Pancaran Kasih Manado.
\end{abstract}

Kata Kunci : Pengetahuan; Sikap; Luka Perineum

\section{PENDAHULUAN}

Sustainable Development Goals (SDGs) menargetkan pada tahun 2015 dapat menurunkan angka kematian ibu mencapai 110/100.000 kelahiran hidup dan angka kematian bayi 23/1000 kelahiran hidup. Angka Kematian Ibu (AKI) dan Angka Kematian Bayi (AKB) merupakan salah satu indikator pembangunan kesehatan dalam RPJMN 2015-2019 dan SDGs ${ }^{(1)}$

Hasil Survei Demografi dan Kesehatan Indonesia (SDKI) 2007 menunjukkan angka kematian ibu meningkat tajam di tahun 2012. Survei menemukan angka kematian ibu tahun 2007 sebanyak 228/100.000 kelahiran sedangkan pada tahun 2012 menjadi 359/100.000 kelahiran hidup. Angka kematian ibu melahirkan ini merupakan yang tertinggi di kawasan Asia Tenggara (ASEAN) ${ }^{(1)}$.

Robekan perineum umumnya terjadi pada garis tengah dan bisa menjadi luas apabila kepala janin lahir terlalu cepat. Robekan perineum terjadi pada hampir semua primipara. Perdarahan pasca 
persalinan dengan uterus yang berkontraksi baik biasanya disebabkan oleh robekan serviks atau vagina ${ }^{(2)}$.

Hasil penelitian oleh Pasiowan dkk, 2015 di Rumah Sakit Jiwa Prof. Dr.V. L Ratumbuysang Manado pada 3 bulan terakhir tahun 2013 terdapat 98 ibu yang bersalin dan $82(83,67 \%)$ ibu bersalin dengan robekan jalan lahir. Primipara 53 (54\%) 40 episiotomi 13 robekan perineum, multipara 29 ( $29 \%$ ) 15 episiotomi dan 14 robekan perineum.

Cidera jaringan penyokong, baik akut maupun nonakut, yang telah diperbaiki atau belum, dapat menjadi masalah ginekologis dikemudian hari. Kerusakan pada penyokong panggul biasanya segera terlihat dan diperbaiki setelah persalinan (3)

Kasus kematian ibu Provinsi Sulawesi Utara tahun 2015 mengalami peningkatan dibandingkan dengan tahun 2014, dimana pada tahun 2015 terdapat 71 kasus meningkat dibandingkan dengan tahun 2014 yang hanya 58 kasus kematian. Penyebab, kematian ibu bersalin sebagian besar disebabkan oleh pendarahan 22 kasus, hipertensi dalam kehamilan 13 kasus, infeksi 5 (lima) kasus, dan lain-lain 31 kasus ${ }^{(4)}$.

Hasil survei awal yang dilakukan pada bulan Februari, terdapat data dari 3 bulan terakhir sejak 2017 di RSU GMIM Pancaran Kasih Manado, sebanyak 249 total keseluruhan partus dan 66 orang pasien postpartum yang mempunyai luka perineum. Dari wawancara langsung pada tanggal 3 Februari 2018 dengan 1 orang pasien Postpartum hari ke-3 P2A0 yang masih dalam proses perawatan, mengatakan belum bisa beraktifitas dengan normal karena luka perineum masih terasa nyeri, dan ibu merasa tidak nyaman.

Pada wawancara kedua tanggal 7 Februari 2018 terhadap tenaga kesehatan, mengatakan bahwa 1 tahun terakhir pada 2017, ada pasien yang dirawat karena mengalami luka perineum yang terbuka. Pasien sebelumnya telah pulang kerumah dan kembali ke rumah sakit karena luka perineum yang terbuka. Namun ibu tidak bersalin di RSU GMIM Pancaran Kasih Manado.

Dari data yang diperoleh melalui buku register kunjungan pasien, terdapat 1 ibu postpartum hari ke-9 umur 34 tahun P2A0 HC: L:3 yang dirawat pada awal bulan Januari tanggal 05-01-2017 karena mengalami luka perineum yang terbuka 
saat ibu dalam pemulihan pasca bersalin dirumahnya.

Berdasarkan uraian masalah diatas, maka peneliti tertarik untuk melakukan penelitian dengan judul hubungan pengetahuan dengan sikap ibu nifas tentang perawatan luka perineum di RSU GMIM Pancaran Kasih Manado.

Upaya pemantauan yang melekat dan asuhan pada ibu dan bayi yang baik pada masa nifas di harapkan dapat mencegah kejadian tersebut ${ }^{(5)}$. Perilaku personal hygiene atau kebersihan diri adalah suatu usaha kesehatan perorangan untuk dapat memelihara kesehatan diri sendiri, memperbaiki dan mempertinggi nilai-nilai kesehatan serta mencegah timbulnya penyakit.

\section{METODE}

Jenis penelitian ini merupakan penelitian observasional analitik, yaitu penelitian yang menjelaskan adanya hubungan antara variable melalui

\section{Gambaran Umum Responden}

pengujian hipotesa. Penelitian ini dilaksanakan di RSU GMIM Pancaran Kasih Manado, penelitian ini dilakukan pada bulan Mei-Juli 2018. Populasi dalam penelitian ini adalah data 3 bulan terakhir 2017 sampai 2018 pada ibu nifas dengan luka perineum di RSU GMIM Pacaran Kasih Manado yang berjumlah 66 orang. Instrumen yang digunakan dalam penelitian ini adalah kuesioner yang terdiri dari karakteristik responden (usia, pendidikan, pekerjaan, paritas). Peneliti menggunakan kuesioner yang bejumlah 20 pernyataan yang sudah disusun secara terstruktur. Teknik analisa data dalam penelitian ini yaitu Analisis Univariate dan Analisis Bivariat Untuk melihat hubungan antara dua variabel bebas dan variabel terikat menggunakan Uji statistik ChiSquare pada tingkat kemaknaan $\mathrm{p}<0,05$ dengan confidence interval $95 \%$ dan data diolah dengan menggunakan SPSS.

\section{HASIL}


Tabel 1 Distribusi responden berdasarkan usia, pendidikan, pekerjaan dan paritas di RSU GMIM Pancaran Kasih Manado Tahun 2018

\begin{tabular}{|c|c|c|}
\hline \multirow{2}{*}{ Karakteristik Responden } & \multicolumn{2}{|c|}{ Jumlah } \\
\hline & $\mathrm{f}$ & $\%$ \\
\hline \multicolumn{3}{|l|}{ Usia } \\
\hline$<20$ & 2 & 5 \\
\hline $20-35$ & 34 & 85 \\
\hline$>35$ & 4 & 10 \\
\hline \multicolumn{3}{|l|}{ Pendidikan } \\
\hline Dasar & 17 & 42,5 \\
\hline Menengah & 19 & 47,5 \\
\hline Tinggi & 4 & 10 \\
\hline \multicolumn{3}{|l|}{ Pekerjaan } \\
\hline IRT & 28 & 70 \\
\hline Swasta & 7 & 17,5 \\
\hline PNS & 5 & 12,5 \\
\hline \multicolumn{3}{|l|}{ Paritas } \\
\hline Primipara (1) & 22 & 55 \\
\hline Multipara (2-5) & 18 & 45 \\
\hline
\end{tabular}

Berdasarkan table 1 menunjukkan dari 40 responden terbanyak berusia 20-35 tahun berjumlah 34 (85 \%). Tingkat pendidikan dari 40 responden yang terbanyak yaitu Pendidikan Menengah responden terbanyak sebagai Ibu Rumah Tangga yaitu $28 \quad(70 \%)$ dan paritas terbanyak adalah primipara berjumlah 22 responden $(55 \%)$.

\section{Analisis Univariat Variabel Penelitian}

Tabel 2. Distribusi Responden Menurut Kategori Pengetahuan dan Sikap Ibu Nifas Tentang Perawatan Luka Perineum

\begin{tabular}{lcc}
\hline \multirow{2}{*}{ Variabel } & \multicolumn{2}{c}{ Jumlah } \\
\cline { 2 - 3 } & $\mathrm{f}$ & $\%$ \\
\hline Pengetahuan & & \\
$\quad$ Baik & 19 & 47,5 \\
$\quad$ Kurang & 21 & 52,5 \\
Sikap & & \\
$\quad$ Negatif & 25 & 62,5 \\
Positif & 15 & 37,5 \\
\hline
\end{tabular}

Tabel 2 menunjukkan bahwa Kategori sikap terbanyak responden responden terbanyak memiliki kategori memiliki sikap negatif tentang Perawatan pengetahuan tentang perawatan luka Luka Perineum berjumlah $25(62,5 \%)$. perineum kurang berjumlah $21(52,5 \%)$. 


\section{Analisis Bivariat Variabel Penelitian}

Tabel 3. Hubungan Pengetahuan dengan Sikap Ibu Nifas tentang Perawatan Luka Perineum di RSU GMIM Pancaran Kasih Manado Tahun 2018

\begin{tabular}{|c|c|c|c|c|}
\hline \multirow{2}{*}{$\begin{array}{c}\text { Tingkat } \\
\text { Pengetahuan }\end{array}$} & \multicolumn{2}{|c|}{ Ada } & \multirow[t]{2}{*}{$\mathbf{F}$} & \multirow[t]{2}{*}{$P$} \\
\hline & Negatif & Positif & & \\
\hline Baik & $8(42,1 \%)$ & $11(57,9 \%)$ & $19(47,5 \%)$ & 0,021 \\
\hline
\end{tabular}

Tabel 3, menunjukkan ibu yang mempunyai pengetahuan kurang memiliki sikap negatif terhadap perawatan Luka Perineum lebiih banyak $81 \%$, dan informasi. Semakin tinggi tingkat dibandingkan dengan ibu yang memiliki pengetahuan baik lebih banyak sikap positif $57,9 \%$. Hasil analisis statistik yang menggunakan uji Chi Square diperoleh nilai Exact Sig. (2-sided) 0.021, menunjukkan hasil signifikan lebih kecil dari 0.05 nilai $\mathrm{p}<\alpha(0.021<0.05)$.

\section{PEMBAHASAN}

Hasil penelitian ini menunjukkan pengetahuan tentang Perawatan Luka Perineum pada sebagian besar responden di RSU GMIM Pancaran Kasih Manado adalah baik sebanyak 21 responden (100\%). Hal ini merupakan suatu keadaan dimana pengetahuan baik tentang Perawatan Luka Perineum diperkuat bahwa responden mengerti tentang perawatan Luka Perineum. Adapun faktorfaktor yang mempengaruhi pengetahuan seseorang menurut Mubarrak adalah tingkat pendidikan, pekerjaan, umur, pengetahuan ibu, dalam memahami informasi tentang Perawatan Luka Perineum sehingga meningkatkan pengetahuannya tentang infeksi luka perineum (6). Dalam penelitan ini pengetahuan tentang perawatan Luka Perineum dipengaruhi oleh tingkat pendidikan responden dimana tingkat pendidikan responden paling banyak adalah Menengah sebesar 47,5\% responden dengan pekerjaan responden sebesar $70 \%$ responden.

Menurut Koentjoroningrat yang dikutip oleh Puspitarani, makin tinggi pendidikan seseorang, makin mudah menerima informasi, sehingga makin banyak pula pengetahuan yang dimiliki dan sebaliknya bila pendidikan yang kurang akan menghambat perkembangan sikap seseorang terhadap nilai-nilai baru yang diperkenalkan. Tingkat Pendidikan yang tinggi akan mempermudah seseorang menerima informasi, sehingga makin banyak pula pengetahuan yang dimiliki minat, pengalaman, kebudayaan sekitar 
khususnya mengenai perawatan luka perineum.

Hasil penelitian ini menunjukkan bahwa Sikap Ibu Nifas tentang Perawatan Luka Perineum pada sebagian besar responden di RSU GMIM Pancaran Kasih Manado adalah Negatif yang artinya tidak tau langkah-langka yang benar dalam melakukan perawatan luka perineum dengan tepat sebanyak 25 responden $(62,5 \%)$. Sikap responden yang tidak melakukan perawatan luka perineum dengan benar mempunyai alasan bahwa akan memakan banyak waktu dan kurangnya pemahaman dalam melakukan vulva hygiene yang benar. Hal ini tersebut dikemukakan oleh Emilia menyebutkan ada empat faktor yang mempengaruhi perilaku hidup sehat yaitu motivasi, kemampuan, persepsi, dan kepribadian ${ }^{(7)}$.

Hal ini berkaitan dengan faktorfaktor yang mempengaruhi sikap seseorang seperti informasi dari petugas kesehatan tentang PHBS dalam hal ini tentang vulva hygiene.

Menurut hasil penelitian Saputri pengetahuan yang baik diikuti dengan sikap ibu yang positif sedangkan Pengetahuan yang kurang lebih cenderung bersikap negatif. Sikap ibu untuk melakukan perawatan luka perineum dipengaruhi informasi yang diterima mengenai perawatan tersebut.

Dari hasil analisis tabulasi silang (crosstab) diketahui 19 responden yang memiliki pengetahuan baik, untuk responden yang memiliki pengetahuan baik dan sikap positif sebanyak 11 responden $(57,9 \%)$, dan untuk responden yang memiliki pengetahuan baik tapi sikap negatif sebanyak 8 responden $(42,1 \%)$. Sedangkan responden yang memiliki pengetahuan kurang sebanyak 21 responden, yang memiliki pengetahuan kurang dengan sikap negatif sebanyak 17 responden (81\%) dan responden yang memiliki pengetahuan kurang tapi sikap positif sebanyak 4 responden (19\%). Sehingga terlihat bahwa semakin kurang pengetahuan responden, maka akan cenderung bersikap negatif terhadap perawatan luka perineum.

Hasil uji Chi Square diperoleh nilai Exact Sig. (2-sided) sebesar 0.021 menunjukkan hasil signifikan lebih kecil dari $0.05(0.021<0.05)$, maka disimpulkan bahwa H1 diterima artinya ada hubungan yang signifikan antara pengetahuan dengan sikap ibu nifas tentang perawatan luka perineum di RSU GMIM Pancaran Kasih Manado. Hasil penelitian ini sejalan dengan penelitian dari Herawati yang dimana hasil uji statistik Chi-square 
dengan 24 responden didapatkan nilai $\mathrm{X}^{2}$ hitung $>\mathrm{X}^{2}$ tabel $(8,327>3,481)$ dan $\mathrm{p}=$ 0,004 dimana $\alpha=0,05$, sehingga $\mathrm{H} 1$ diterima artinya terdapat hubungan perawatan perineum dengan kesembuhan luka perineum pada ibu nifas hari keenam di BPS Ny. Sri Suhersi, Mojokerto, Kedawung, Sragen. Hasil yang menunjukkan nilai positif (+) berarti semakin baik perawatan perineum, semakin cepat penyembuhan luka perineum $^{(8)}$.

Menurut Siti anah dkk sebagian besar ibu nifas berpengetahuan baik 18 orang $(45,0 \%)$ dan cukup 18 orang $(45,0 \%)$. Hal ini dimungkinkan karena berbagai faktor yang mempengaruhi pengetahuan salah satunya adalah informasi. Dimana informasi akan memberikan pengaruh kepada seseorang meskipun orang tersebut mempunyai tingkat pendidikan rendah tetapi jika orang tersebut mendapatkan informasi yang baik dari berbagai media maka hal ini dapat meningkatkan pengetahuan orang tersebut.

Pengetahuan yang tinggi belum menjamin seseorang untuk memiliki sikap yang baik (positif). Hal ini dikarenakan selain pengetahuan, ada banyak faktor yang mempengaruhi perilaku diantaranya adalah kepercayaan, keyakinan, nilai-nilai, tersedia tidaknya fasilitas atau sarana kesehatan serta perilaku petugas kesehatan (9).

Pengetahuan merupakan faktor yang penting namun tidak memadai dalam perubahan perilaku kesehatan. Pengetahuan seseorang mengenai kesehatan mungkin penting sebelum perilaku terjadi, tetapi tindakan kesehatan yang diharapkan mungkin tidak akan terjadi kecuali seseorang mempunyai motivasi untuk bertindak atas dasar pengetahuan yang dimilikinya ${ }^{(\mathbf{1 0})}$.

Menurut teori yang ada sikap itu merupakan kesiapan atau kesediaan untuk bertindak dan bukan merupakan pelaksanaan motif tertentu. Sikap merupakan kesiapan untuk bereaksi terhadap objek tertentu sebagai suatu penghayatan yang terdiri dari menerima, merespon, menghargai dan bertanggungjawab. Sikap akan diikuti atau tidak oleh suatu tindakan berdasarkan pada sedikit atau banyaknya pengalaman seseorang (11).

\section{KESIMPULAN}

Hasil penelitian menunjukan ada hubungan antara pengetahuan dengan sikap ibu nifas tentang perawatan luka perineum di RSU GMIM Pancaran Kasih Manado nilai. 


\section{DAFTAR PUSTAKA}

1. Yohana T, Korah B, Dompas R. Hubungan Pengetahuan Dengan Sikap Tenaga Kesehatan Tentang Pencegahan Infeksi Pada Prtolongan Persalinan. J Ilm Bidan. (2015)

2. Pasiowan S, Lontaan A, Rantung M. Faktor-Faktor Yang Berhubungan Dengan Robekan Jalan Lahir Pada Ibu Bersalin. J Ilm Bidan. (2015)

3. Bobak I, Lowdermilk, Jensen. Buku Ajar Keperawatan Maternitas. Jakarta: EGC; (2012).

4. Dinas Kesehatan Provinsi Sumatera utara. Profil Kesehatan Provinsi Sumatera Utara Tahun 2016.

http://www.depkes.go.id/resources/download/profil/PROFIL_KAB_KOTA_2016/1275_Sumut_ Kota_Medan_2016.pdf. 2016.

5. BKKBN. Deteksi Dini Komplikasi Persalinan. Jakarta: BKKBN; (2006).

6. Mubarok W. Promosi Kesehatan: Sebuah Pengantar Proses Belajar Mengajar dalam Pendidikan. Yogyakarta: Graha Ilmu; (2007).

7. Emilia R. Pengaruh Promosi Kesehatan tentang ASI Eksklusif terhadap Pengetahuan dan Sikap Ibu Hamil di Mukim Laure-e Kecamatan Simeulue. Medan: , Fakultas Ilmu Kesehatan Masyarakat Universitas Sumatera Utara; (2008).

8. Herawati P. Hubungan Perawatan Perineum dengan Kesembuhan Luka Perineum pada Ibu Nifas Hari Keenam di Bidan Praktik Swasta (BPS) Ny. Sri Suhersi Mojokerto Kedawung Sragen. (2010).

9. Notoadmodjo S. Kesehatan Masyarakat:Ilmu \& Seni. Edisi Revi. Jakarta: Rineka Cipta; (2011).

10. Notoadmodjo S. Promosi Kesehatan Dan Perilaku Kesehatan. Jakarta: Rineka Cipta; (2014). 1$247 \mathrm{p}$.

11. Notoadmodjo. Pengantar Ilmu Perilaku Kesehatan. Jakarta: Rineka Cipta. (2010). 
